\title{
TAXONOMIC NOTES ON SOME STYRAX (STYRACACEAE) SPECIES FROM BRAZIL
}

\author{
Peter W. Fritsch \\ Botanical Research Institute of Texas \\ 1700 University Dr. \\ Fort Worth, Texas 76107-3400, U.S.A. \\ pfritsch@brit.org
}

\begin{abstract}
Taxonomic issues regarding three species of Styrax ser. Valvatae in Brazil are addressed. Styrax bahiensis, a new species from Bahia state, northeastern Brazil, is described and illustrated. It is similar to S. pallidus in its leaves of similar size and anther thecae that exceed the connective, but differs by coriaceous leaf blades with a revolute margin, leaf domatia up to $0.7 \mathrm{~mm}$ long and flat or rarely slightly bulging, a yellow- or orange-stellate-tomentulose calyx abaxially, and spreading corolla lobes. The species is known only from the type collection gathered over 50 years ago. Styrax griseus is placed in synonymy under S. kuhlmannii, a species from central Brazil, and a lectotype is provided for S. kuhlmannii. An updated description and estimate of the geographic distribution of S. pauciflorus are provided, as well as a lectotype and conservation assessment for this species.
\end{abstract}

Key Words: Bahia, Brazil, endemic, new species, Styrax, synonymy

RESUMO

Questões taxonômicas relacionadas a três espécies de Styrax ser. Valvatae no Brasil são abordadas. Styrax bahiensis, uma nova espécie do estado da Bahia, no nordeste do Brasil, é descrita e ilustrada. Essa espécie é semelhante à S. pallidus em suas folhas de tamanho similar e nas tecas das anteras que excedem o conectivo, mas diferem por lâminas coriáceas com margem revoluta, domácias de até 0,7 mm de comprimento e planas ou raramente um pouco protuberantes, cálice abaxialmente estrelado tomentoso de cor amarela ou laranja e lóbulos da corola espalhados. A espécie é conhecida apenas pelo material tipo coletado há mais de 50 anos. Styrax griseus é sinonimizado sob S. kuhlmannii, uma espécie da região central do Brasil, e um lectótipo é selecionado para S. kuhlmannii. Uma descrição atualizada, a distribuição geográfica estimada e um parecer do status da conservação de S. pauciflorus são fornecidas, assim como um lectótipo selecionado para esta espécie.

\section{INTRODUCTION}

Styrax L. ser. Valvatae Perkins (Styracaceae) comprises ca. 90 species distributed widely in the Neotropics (Fritsch 1999). The series is part of Styrax sect. Valvatae Gürke defined by an evergreen habit, bases of young shoots without distinctly stalked trichomes, and a subcoriaceous corolla with valvate aestivation and straight sides in outline. The series is distinguished from Styrax ser. Benzoin P.W. Fritsch by various fruit characters and a geographic distribution in the Neotropics (versus Paleotropics and Old World subtropical; Fritsch 1999).

During specimen examination for the treatment of Styrax for the project Flora do Brasil 2020 (Flora do Brasil 2020) and as part of continuing taxonomic work on the genus worldwide (e.g., Fritsch 1997, 2004, 2010, 2015, 2017; Huang et al. 2003; Fritsch et al. 2002, 2015; Fritsch \& Steyermark 2005; Li \& Fritsch 2018), it became apparent that several taxonomic issues regarding Styrax ser. Valvatae from Brazil, brought to light from herbarium material either on loan to the author or available as digital images of herbarium specimens through online data portals, should be addressed. Here a new species is described, a species name is placed in synonymy of another whose taxonomic status until now remained unclear, and an expanded description for a species is presented along with new geographic information that establishes it as a narrow endemic to southern Bahia state.

\section{A NEW SPECIES OF STYRAX FROM BAHIA}

A specimen of Styrax collected in 1970 from Bahia state, Brazil, on loan to the author from the Missouri Botanical Garden (MO), was found to possess an unusual suite of characters. On careful examination of this 
material, and in consultation with relevant taxonomic literature (Perkins 1907; Wallnöfer 1997; Fritsch 1999, 2004, 2010, 2015, 2017; Fritsch et al. 2002; Fritsch \& Steyermark 2005; Asprino \& Amorim 2014), it was confirmed that it represents a species of Styrax new to science. The new species is described and illustrated here.

Styrax bahiensis P.W. Fritsch, sp. nov. (Fig. 1). TYPE: BRAZIL. BAHIA: [Mun. Belmonte:] Santa Maria Eterna, 8 to 9 km from the

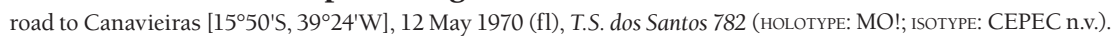

Haec species Styraci pallido A. DC. simillima, sed ab eo laminis coriaceis ad marginem revolutis, domatiis laminae usque ad $0.7 \mathrm{~mm}$ longa et planis vel parum protuberantibus, calyce externo luteo- vel aurantiaco-stellato-tomentuloso, lobis corollae effusis differt.

Description.-Trees, evergreen, $8 \mathrm{~m}$ tall. Young branchlets 2.1-3.2 mm wide, dark brown-stellate-tomentulose with trichomes up to $0.24 \mathrm{~mm}$ diam.; mature branchlets dark maroon with longitudinally fissured whitish epidermis, glabrous. Leaves: petioles $12-16 \times 1.9-2.4 \mathrm{~mm}$, dark brown-stellate-tomentulose, abaxially irregularly ridged, adaxially caniculate; blades oblong-elliptic, 9.3-14.0 × 4.6-7.0 cm, 1.9-2.1 times as long as wide, coriaceous, abaxially uniformly brownish gray- to greenish gray-stellate-tomentulose to the naked eye, vein surfaces scarcely visible beneath tomentum, trichomes up to $0.14 \mathrm{~mm}$ diam. with arms up to ca. 20 and up to $0.20 \mathrm{~mm}$ long, mixed with scattered ferrugineous stellate trichomes of the same size, the latter especially prevalent near and on major veins; adaxially yellowish brown to greenish brown when dry, brown-stellatetomentulose on midvein proximally otherwise glabrous; midvein abaxially prominent, adaxially sulcate; secondary veins 6 to 8 on each side of midvein, abaxially prominent with usually flat or rarely bulging axillary marsupiform domatia up to $0.7 \mathrm{~mm}$ long, adaxially sulcate; tertiary and quaternary veins abaxially raised, adaxially raised and forming a conspicuous reticulum; base broadly cuneate to subrounded; margin entire, revolute; apex obtuse to slightly acuminate. Inflorescences pseudoterminal and in leaf axils or rarely borne proximal to leaves along branchlet, paniculate, $3.7-6.6 \mathrm{~cm}$ long, 8- to ca. 15-flowered, peduncle and branches orangish brown-stellate-tomentulose, peduncle $1.2-2.0 \mathrm{~cm} \times 1.1-1.5 \mathrm{~mm}$, branches $1.0-1.2 \mathrm{~cm}$ long. Pedicels 3.9-5.4 $\times 0.7-1.1 \mathrm{~mm}$, orangish brown- to yellowish brown-stellate-tomentulose; bracteoles mostly caducous, linear-subulate, 1.4-1.8 mm long, stellate-tomentulose. Flowers hermaphroditic, 13-16 mm long. Calyx cupuliform-obconic, 4.2-5.0 × 4.2-6.2 mm, abaxially uniformly yellow- or orange-stellate-tomentulose with trichomes at mid-calyx up to $0.16 \mathrm{~mm}$ diam., adaxially white-stellate-sericeous, margin eglandular, truncate between the teeth, teeth 4 to 6 , up to $0.4 \mathrm{~mm}$ long, deltoid. Corolla with valvate aestivation, white, campanulate, 12.3-12.5 mm long, petals connate up to calyx margin; lobes 5, diverging from each other at same point as stamen tube from corolla, spreading, linear, 9.0-11.0 × 1.8-2.5 mm, abaxially densely lepidote to stellatepubescent, adaxially stellate-pubescent near margin and apex otherwise glabrous, apex acute. Stamens 10; stamen tube diverging from corolla at ca. $2 \mathrm{~mm}, 0.5-1.0 \mathrm{~mm}$ long, glabrous; distinct portion of filaments straight, of equal width throughout, 1.8-2.0 mm long, margins flattened, dorsally sparsely stellate-pubescent, ventrally without auricles, ventral surface bearing a dense mass of golden yellow stellate trichomes with arms of trichomes straight and generally parallel to filaments, upward-pointing arms predominant, up to $1.2 \mathrm{~mm}$ long, downward-pointing arms up to $0.5 \mathrm{~mm}$ long; anthers $4.7-5.4 \mathrm{~mm}$ long, connectives \pm as wide as thecae in ventral view, glabrous; thecae linear, apically non-tapered, exceeding connective, sparsely stellate-pubescent at margins. Free portion of ovary conical-dome-shaped, 1.4-1.5 × 1.9-2.4 mm, golden brown-stellatetomentulose, trichomes up to $0.16 \mathrm{~mm}$ diam. with arms up to $0.06 \mathrm{~mm}$ long; style $10.3-10.4 \mathrm{~mm}$ long, glabrous; stigma truncate, 0.6-0.7 mm wide. Fruit unknown.

Distribution, Habitat, and Phenology.-Styrax bahiensis is known only from the type collection made in "mata" (forest) in Mun. Belmonte near Santa Maria Eterna. It was collected in flower in May.

Conservation Assessment.-The Atlantic Coastal Forest biome is a global biodiversity hotspot, and within this region the forests of southern Bahia appear to hold the highest levels of species richness and plant endemism (Thomas et al. 2008). In this context, the discovery of a new endemic species of Styrax in southern Bahia is consistent with the high levels of plant diversity and endemism reported for the region, although it is possible that with further sampling the species may be found to be distributed more widely. Because the species is only known from the type collection, the category "Data Deficient" (DD) is recommended for S. bahiensis in accordance with the International Union for Conservation of Nature Red List criteria (IUCN Standards and 


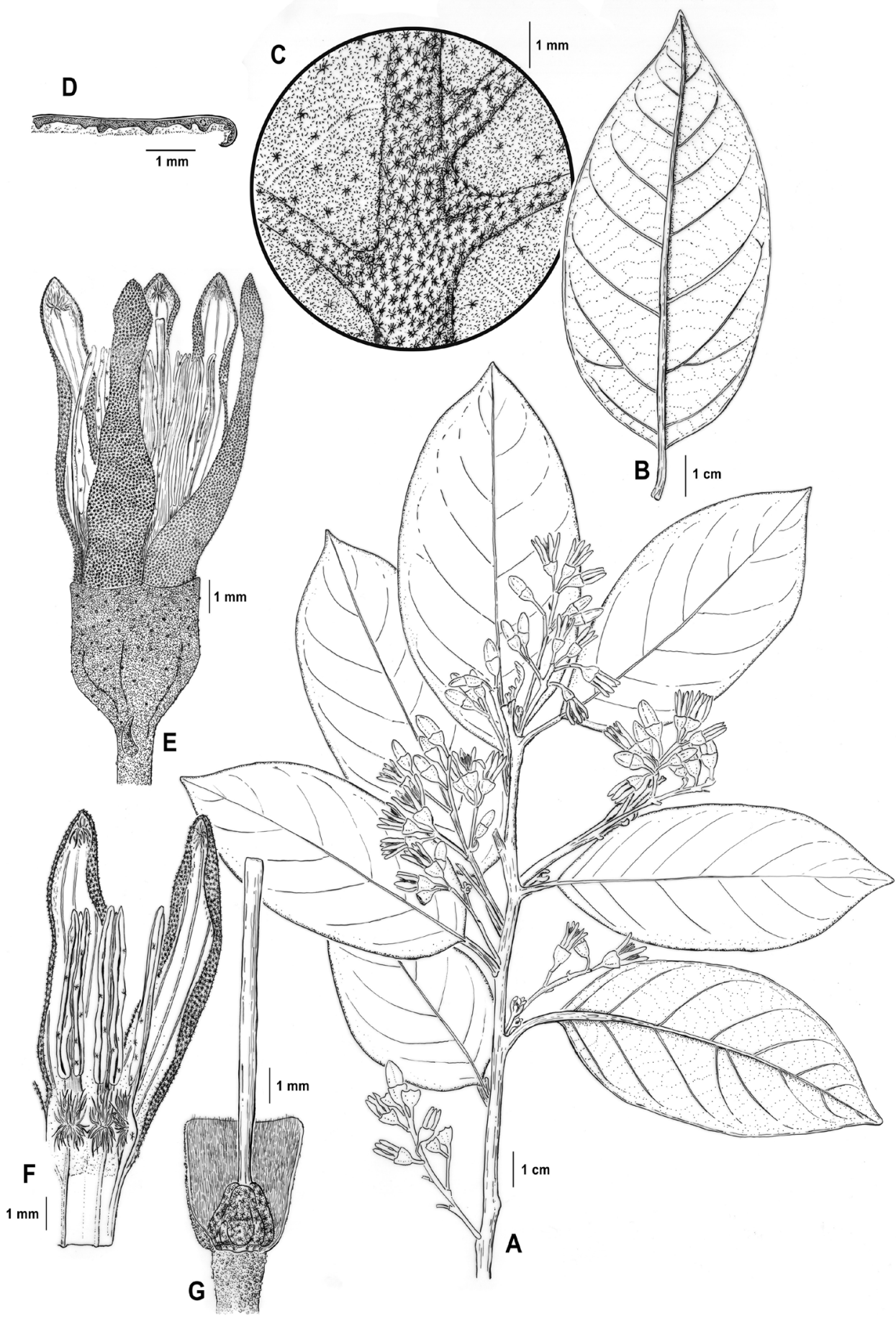

FIG. 1. Styrax bahiensis. A. Flowering branchlet with leaves in adaxial view and (lower right) abaxial view. B. Detail of leaf in abaxial view. C. Leaf blade, abaxial surface showing midvein, three secondary veins, and domatia. D. Cross section of leaf blade (adaxial surface toward top) showing revolute margin. E. Upper part of pedicel showing bracteole, and flower. F. Corolla cut longitudinally to show adaxial surface of corolla and part of androecium. G. Calyx and gynoecium with calyx cut open ventrally to show upper part of ovary. Based on the holotype (dried material). 
Petitions Subcommittee 2019). The region of Santa Maria Eterna appears not to be protected by any conservation unit. Attempts should be made to relocate the original population and survey additional populations in the area where the collection was made to provide a more definitive conservation assessment for the species.

Discussion.-Styrax bahiensis possesses a combination of characters that places it solidly within the clade of Styrax sect. Valvatae. It has an (apparently) evergreen habit, bases of young shoots without distinctly stalked trichomes, and a subcoriaceous corolla with valvate floral aestivation and straight sides in outline (Fritsch 1999, 2001). It also can be placed confidently within Styrax ser. Valvatae. This series is most readily distinguished from Styrax ser. Benzoin, the other series in the section, by fruit characters. Although the fruit of the new species is unknown, the new species can nonetheless be placed in Styrax ser. Valvatae by other characters, i.e., the presence of trichomes on the ventral portion of the stamen filament with coarse arms parallel to the filaments generally $\geq 1 \mathrm{~mm}$ long (up to $1.2 \mathrm{~mm}$ long in the new species), a character unique to this series within Styrax (Fritsch 1999), and a geographic distribution restricted to the Neotropics. As such, the fruit of the new species is expected to be a fleshy drupe with a smooth ellipsoid seed (Fritsch 1999). By its hermaphroditic condition and flowers $>10 \mathrm{~mm}$ long it is placed in Styrax subser. Latifoli P.W. Fritsch, which includes all but 10 species of the series (Fritsch et al. 2015; Fritsch 2017).

Styrax bahiensis is most similar to S. pallidus A. DC., a wide-ranging but uncommonly collected species from Colombia, Venezuela, the Guianas, and Brazil (P.W. Fritsch, unpubl. data). In Brazil, S. pallidus has been collected from the states of Amapá, Amazonas, Ceará, Rio de Janeiro, and Bahia (e.g., Porto Seguro: Parque Nacional Monte Pascoal, 17 July 1997, W.W. Thomas et al. 11587 (CAS!, NY n.v.)). The two species share leaf blades of similar size, marsupiform domatia in the axils of at least some of the secondary veins abaxially, and anther thecae that exceed the connective (a character that is uncommon in Styrax ser. Valvatae). The new species can be distinguished from S. pallidus by coriaceous leaf blades with a revolute margin (versus chartaceous with a planar margin), leaf domatia up to $0.7 \mathrm{~mm}$ long and flat or rarely slightly bulging (versus up to 1.7-2.4 $\mathrm{mm}$ long and prominently bulging), a yellow- or orange-stellate-tomentulose calyx on the external surface (versus grayish green-stellate tomentulose), and corolla lobes that are spreading (versus strongly reflexed). In addition, in S. bahiensis the abaxial tomentum of the leaf blades is brownish gray to greenish gray to the naked eye (versus grayish green in S. pallidus) and the abaxial surfaces of the veins of the leaf blades are less easily visible through the pubescence than in S. pallidus.

The two other species of Styrax ser. Valvatae of eastern Brazil having anther thecae that exceed the connective are S. camporum Pohl and S. ferrugineus Nees \& Mart. The new species is distinct from S. camporum by coriaceous leaf blades (versus chartaceous), the abaxial surface with a thin tomentum of surface trichomes with arms up to $0.20 \mathrm{~mm}$ long (versus with a thicker tomentum of surface trichomes with arms $>0.20 \mathrm{~mm}$ long); and from $S$. ferrugineus by tertiary and quaternary veins abaxially raised (versus prominent) with surfaces scarcely visible beneath tomentum (versus clearly visible). The new species also superficially resembles S. pohlii A. DC. (the species identification on the label of the MO specimen) in its coriaceous leaf blades (although thicker than S. pohlii) with revolute margin and flowers of similar size. It is consistently distinguished from S. pohlii by its anther thecae that exceed the connectives (versus equal to the connectives). Moreover, S. pohlii usually has an abaxial surface base tomentum of whitish to whitish green trichomes and also larger scattered ferrugineous (rarely white or pale yellow) trichomes with arms $<20$ and $>0.10 \mathrm{~mm}$ long but usually much longer.

\section{SYNONYMY OF STYRAX GRISEUS UNDER S. KUHLMANNII}

The taxonomic status of Styrax kuhlmannii Brade ex C. Aranha, a species from central Brazil (cerrado, riverine/gallery forest, and terra firme forest), has long been unresolved. The species was validly published and an illustration was included (Aranha 1970). The holotype was indicated in the first paragraph of the article as "No. 14.705, col. J.G. Kuhlmann 2.230 em abril de 1918." However, in the "Specimen examined" section following the Latin description, presumably the same specimen as above was indicated as "Brasil, Mato Grosso, prox. Lagoinha, J.G. Kuhlmann No. 2280, aprili anno 1918 leg. (RB 14.705, Holotypus).” The specimen was 
not included as part of a loan of Brazilian Styrax to the author from RB to CAS in the mid-1990s and, in response to a query, the curator at RB indicated that the no type material of this name was housed at RB. Type material of S. kuhlmannii was not included among the many herbarium loans of Brazilian Styrax specimens received by the author, including from $\mathrm{R}$, and none of the many hundreds of sheets of Brazilian Styrax were annotated as S. kuhlmannii. As far as the author can tell, the name appears to have been largely or completely ignored after its publication. Styrax kuhlmannii has been denoted as an "ambiguous" name in the World Flora Online database (http://www.worldfloraonline.org). The illustration included in the protologue is of poor quality and shows little more than general Styrax characters.

In 2020, the author found two digital specimen records (IAC and R) of the type material of Styrax kuhlmannii from a search on the combination of the collector name "Kuhlmann" and the collection number "2230" in the INCT-Herbario Virtual da Flora e dos Fungos specimen portal (http://inct.splink.org.br). An additional specimen housed at SP was discovered with this search, along with the R specimen, on JStor Global Plants (https://plants.jstor.org). No records of Styrax were returned on searches of this combination of terms in the Herbário Virtual REFLORA database (http://floradobrasil.jbrj.gov.br/reflora/herbarioVirtual/ ConsultaPublicoHVUC/ConsultaPublicoHVUC.d). No records of Styrax were returned under the combined search "Kuhlmann" and "2280" in any data portal, strongly suggesting that the 2280 number cited in the protologue is merely a typographic error of 2230. Of the three data records for J.G. Kuhlmann 2230, IAC was indicated as the holotype, R as an isotype, and the one at SP merely as "type." Only the R and SP records were accompanied by a digital image of the specimen.

Examination of these images leaves no doubt that Styrax kuhlmannii is the same species as S. griseus P.W. Fritsch (Fritsch 2004; e.g., leaves of similar size and shape (ovate-elliptic), abaxial surfaces to the naked eye dull gray or greenish gray with contrasting darker major veins, and revolute margin). Fritsch (2004) indicated that the first collection of the species was made in 1964 (Fritsch was not aware of the J.G. Kuhlmann 2230 collection made in 1918) and stated that at least 36 collections of the species had been made since then. Because S. kuhlmannii was published earlier than S. griseus, S. griseus is here placed as a taxonomic synonym under $S$. kuhlmannii.

Styrax kuhlmannii C. Aranha, Atas Soc. Biol. Rio de Janeiro 13:81 (1970). Type: BRAZIL. Mato Grosso: between Cabeceira ["cabo" in publication] do Lobo and Lagoinha, Apr 1918 (fl), J.G. Kuhlmann 2230 (LECTOTYPE, designated here: IAC 21270 (image!); ;SOLECTOTYPES: R 000027405 n.v. (online image!), SP SP003372 n.v. (online image!)).

Synonym: Styrax griseus P.W. Fritsch, Novon 14:43. 2004. TYPE: BRAZIL. Pará: Marabá, along Highway p/N1, DOCEGEO camp, 20 May 1982 (fl, fr), R.S. Secco, C. Sperling, M. Condon, A. Mesquita, B. Gilberto R. E L. Marinho 257 (holotype: CAS 474689!; isotype: CAS 474688!).

The RB specimen of J.G. Kuhlmann 2230 ([Herbarium] No. 14705), if such exists, is apparently missing. We have designated the IAC specimen as the lectotype because in Aranha (1970) it is indicated that the author of that work received a scholarship from Conselho Nacional de Pesquisas (CNPq) and was an intern of "I.A.C.S.P." (Instituto Agronômico de Campinas). Furthermore, the INCT specimen portal indicates that the IAC specimen is the holotype.

\section{STYRAX PAUCIFLORUS: STATUS AND DISTRIBUTION}

Styrax pauciflorus A. DC. has been a poorly documented species, being only known from the type material, Bahia state, Brazil, year 1834, J.S. Blanchet 1719 (as cited in Perkins (1907): "Herb. De Candolle, Delessert, Brit. Museum" [BM, G, and G-DC]). After the description of the species by Candolle (1844), Seubert (1868), who did not see type material of the species, placed it tentatively in the synonymy of S. pohlii based on the diagnosis. Perkins (1907) was able to examine the type material and recognized it as a distinct species, indicating that it is very different than S. pohlii. Until recently, the only information about this species available to the author was from low-resolution photographs mounted on herbarium sheets housed at F, MICH, MO, and NY of a type specimen from the Conservatoire et Jardin Botaniques Genève (CJBG) combined herbaria, which includes the collections of G (Delessert) and G-DC (De Candolle). Although the photographs are all of the 
same specimen, the labels of the MICH, MO, and NY sheets state "Types of the Delessert Herbarium" at CJBG but the F specimen states "Ex Conservatorio botanico Genevensi (Herb. Prodr. Candoll.)" at CJBG with a hand-written note "Photo of holotype at G-DC."

More recently the author was able to examine a digital image of the specimen on the CJBG herbaria specimen portal (https://www.ville-ge.ch/musinfo/bd/cjb/chg/index.php?lang=en). Based on examination of this image, indicated as housed at G-DC, it is clear that, as Perkins (1907) concluded, it is a distinct species. It is also clear that it is one and the same species as several collections sent as duplicates from various herbaria to CAS and later sent on loan to BRIT. Styrax pauciflorus is distinguished from all species of Styrax ser. Valvatae by the combination of abaxial surfaces of the leaf blades stellate-pubescent but easily visible through the pubescence (i.e., without a base tomentum of minute trichomes); trichomes of the leaf blades abaxially with arms 8 to 14 and up to $1.2 \mathrm{~mm}$ long; stamens twice as many (10) as the corolla lobes (5); and calyces 9-10 $\times$ 5-8 mm and golden yellow-stellate-hispidulous. It appears to be most similar to S. glabratus Schott, a species with a widespread distribution in Central America and tropical South America including Bahia, in its abaxial surface of the leaf blades that is easily visible through any pubescence present, a character that is rare among the species of Styrax ser. Valvatae. However, it is easily distinguished from that species by, e.g., leaves and calyx with stellate trichomes (versus scales).

Styrax pauciflorus A. DC., DC. Prodr. 8:265. 1844. (Fig. 2). TyPe: BRAZIL. BAHIA: year 1834 (fl bud), J.S. Blanchet 1719 (LECTOTYPE, designated here: G-DC G00142291 n.v. (online image!); photographs of G-DC at F!, MICH!, MO!, NY!; ISOLECTOTYPES: BM n.v., G n.v.).

In the protologue, Candolle (1844) cited J.S. Blanchet 1719 as the only collection but the herbarium in which it is housed was not indicated. Because Perkins cited specimens of this collection housed at G-DC, G-DEL, and $\mathrm{BM}$, a lectotype is warranted. The specimen at G-DC was selected as the lectotype because it is Candolle's herbarium, and it is the only specimen that the author has seen. A search of the BM data portal returned negative results. It is not clear why the G-DEL specimen referred to by Perkins does not appear on the CJBG web portal.

Description.-Shrubs or trees, evergreen, up to $7 \mathrm{~m}$ tall. Young branchlets $1.5-2.0 \mathrm{~mm}$ wide, ferrugineous-stellate-hispidulous with trichome arms up to $1.4 \mathrm{~mm}$ long; mature branchlets gray to light brown with fissured epidermis, glabrescent. Leaves: petioles 7-13 × 1.5-2.2 mm, ferrugineous-stellate-hispidulous with scattered blackish globose glands up to $0.2 \mathrm{~mm}$ diam., abaxially \pm rounded, adaxially caniculate; blades dark green to dark greenish brown (in sicco) on both sides, oblong, elliptic, or oblong-oblanceolate, 12.5-22.0 × $4.2-7.3 \mathrm{~cm}, 2.6-3.5$ times as long as wide, subcoriaceous, abaxially sparsely to evenly tawny- to orange-stellate-hispidulous, more densely so on major veins and especially midvein, surface easily visible through pubescence, without a base tomentum, bearing trichomes with 8 to 14 arms with the arms up to $1.2 \mathrm{~mm}$ long, adaxially glabrous except occasionally pubescent on major veins; midvein abaxially prominent, adaxially slightly sulcate to slightly raised; secondary veins 8 to 12 on each side of midvein, not extending to margin, abaxially prominent and without domatia, adaxially slightly raised to slightly sulcate; tertiary and quaternary veins abaxially and adaxially raised; base cuneate to rounded; margin entire, planar; apex acute to short-acuminate. Inflorescences pseudoterminal and in leaf axils, racemose, up to $5 \mathrm{~cm}$ long, 3- to 9-flowered, peduncle and rachis grayish green- to ferrugineous-stellate-hispidulous, peduncle $0.3-1.7 \mathrm{~cm} \times 1.0-1.4 \mathrm{~mm}$, rachis $0.4-1.5 \mathrm{~cm}$ long, bracts linear-subulate, up to $3.5 \mathrm{~mm}$ long, stellate-hispidulous. Pedicels 5.0-7.5 × 1.2-1.5 $\mathrm{mm}$, grayish green- to deep golden yellow-stellate-hispidulous, bracteoles linear subulate, up to $1.5 \mathrm{~mm}$ long, stellate-hispidulous. Flowers hermaphroditic, 18-20 mm long. Calyx elongate-cupuliform, 9-10 × 5-8 mm, abaxially pale to deep golden yellow-stellate-hispidulous on basal half becoming thinly tomentose apically, occasionally with a few scattered ferrugineous trichomes toward base, with trichomes at mid-calyx with arms up to $0.7 \mathrm{~mm}$ long, adaxially white-stellate-sericeous, margin eglandular, truncate between the teeth, teeth 5 , up to $0.6 \mathrm{~mm}$ long, deltoid. Corolla with valvate aestivation, creamy white or white except lobes adaxially rose, campanulate, $15-16 \mathrm{~mm}$ long, petals connate beyond calyx margin up to $1 \mathrm{~mm}$; lobes 5 , diverging from each other at same point as stamen tube from corolla, recurved, linear, 9-12 × 1.8-2.3 mm, abaxially densely 


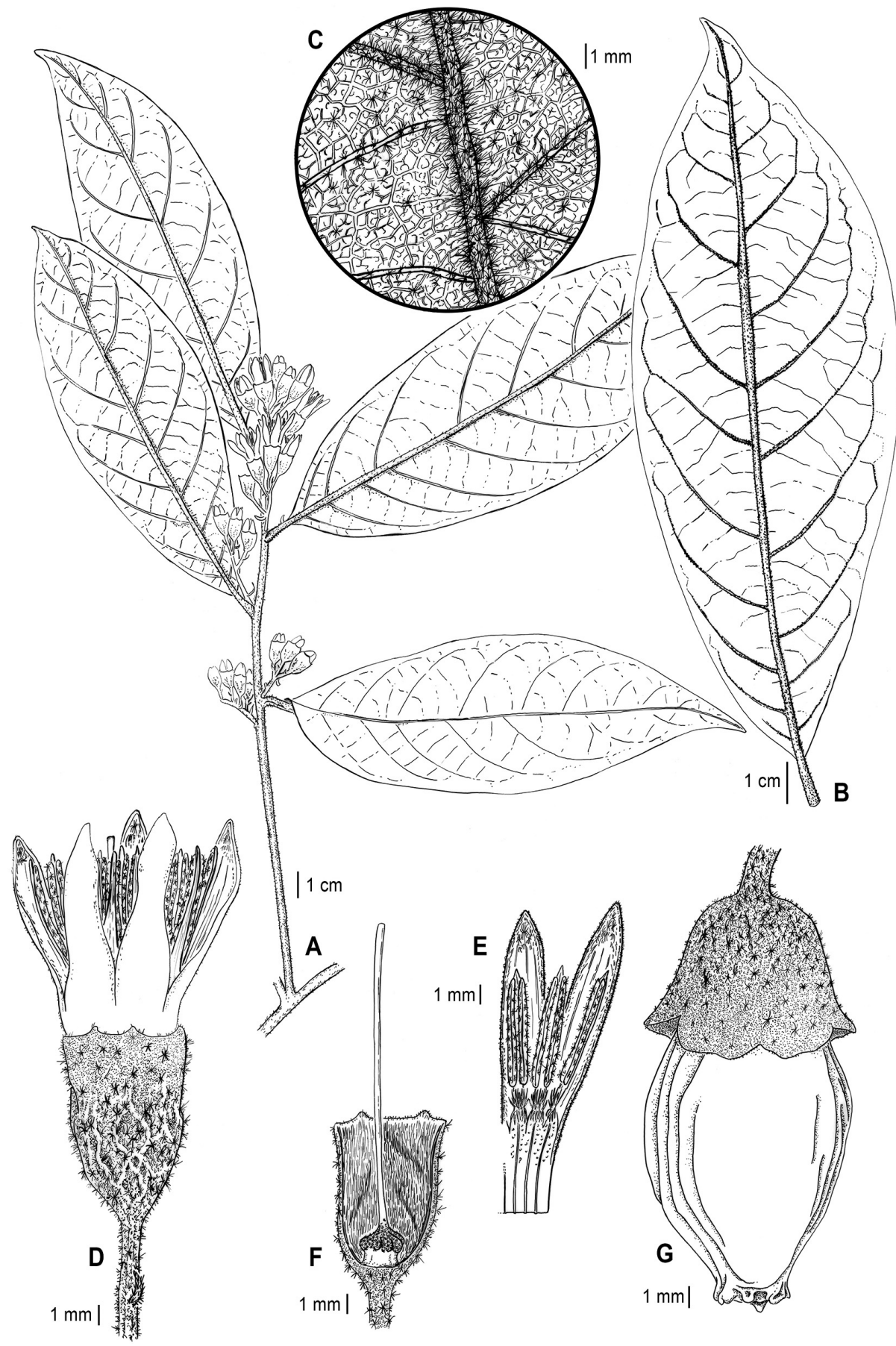

FIG. 2. Styrax pauciflorus. A. Flowering branchlet with leaves in abaxial view and (lower right) adaxial view. B. Leaf, abaxial view. C. Leaf blade, abaxial surface showing midvein, one secondary vein (top) and four tertiary veins. D. Upper part of pedicel showing bracteole, and flower. E. Corolla cut Iongitudinally to show adaxial surface of corolla and part of androecium. F. Calyx and gynoecium with calyx cut open ventrally to show upper part of ovary. G. Fruiting calyx and fruit. A-D based on J.G. Jardim 3045 (CAS); E-F based on A. Eupunino 116 (CAS); G based on H.S. Brito \& S.G. de Vinha 159 (CAS). All based on dried material. 
lepidote to stellate-pubescent, adaxially stellate-pubescent near margin and apex otherwise glabrous, apex acute. Stamens 10; stamen tube diverging from corolla at ca. $4 \mathrm{~mm}$; free portion ca. $1 \mathrm{~mm}$ long, glabrous; distinct portion of filaments straight, of equal with throughout, ca. $1.2 \mathrm{~mm}$ long, margins flattened, dorsally glabrous, ventrally without auricles, ventral surface bearing a dense mass of pale orange stellate trichomes with arms of trichomes slightly curved and spreading, upward-pointing arms predominant, up to $1.2 \mathrm{~mm}$ long, downward-pointing arms up to $0.7 \mathrm{~mm}$ long; anthers $5.8-6.2 \mathrm{~mm}$ long, connectives about as wide as thecae in ventral view, glabrous; thecae linear, apically tapered, exceeded by connective, stellate-pubescent at margins. Free portion of ovary short-cylindrical, ca. $0.9 \times 1.6 \mathrm{~mm}$, laterally glabrous, apex deep golden stellate-tomentose, trichomes with arms up to $0.12 \mathrm{~mm}$ long; style ca. $15 \mathrm{~mm}$ long, glabrous; stigma truncate, ca. $0.5 \mathrm{~mm}$ wide. Drupe ellipsoid, 15-19 × 8-10 mm, apex with irregular annulus 3-6 mm diam. surrounding persistent style base; persistent calyx obconic, 6-8 $\times 8-13 \mathrm{~mm}, 34-50 \%$ of the total length of the fruit.

Distribution, Habitat, and Phenology.-Styrax pauciflorus is endemic to southern Bahia, Brazil, known only from the municipalities of Santa Cruz Cabrália and Una. Mata de restinga, Mata Higrófila Sul Baiana [Tropical Wet Forest of Southern Bahia; Mori \& Silva 1979]. In Flora do Brasil 2020 (Flora do Brasil 2020), the species is listed also for Minas Gerais state but that listing appears to be based on misidentifications of specimens of S. sieberi Perkins from HUF (L.M. Alves 13, G.M. Araújo 316, R.C. Oliveira 10, C.A. Prado 20, C.A. Prado 21, and I. Shiavini 414).

Conservation Assessment.-Whereas the geographic distribution of Styrax pauciflorus was heretofore known only generally as "Bahia" (notwithstanding the misidentified specimens from Minas Gerais indicated above), the updated data from these specimens suggests that the species is a narrow endemic, being known only from the municipalities of Santa Cruz de Cabrália and Una in southern Bahia. Two of the collections indicate a locality in Estação Ecológica do Pau-Brasil, and one in Reserva Biológica de Una (G. Martinelli 9654 could not be located more precisely than the label information of Santa Cruz de Cabrália), suggesting that the species is protected at least to some extent. The category "Near Threatened" (NT) is recommended for S. pauciflorus in accordance with the International Union for Conservation of Nature Red List criteria (IUCN Standards and Petitions Subcommittee 2019) because, although it does not meet the requirements for "Vulnerable," the few collections made suggest that it is rare and therefore may be subject to threat in the near future.

Additional specimens examined.-BRAZIL. Bahia. Mun. Santa Cruz Cabrália: Estação Ecológica do Pau-Brasil, without date (fr), H.S. Brito \& S.G. de Vinha 159 (CAS!, CEPEC n.v.); ibid., 5 Jan 1972 (fl), A. Eupunino [Euponino; Mori \& Silva 1979] 116 (CAS!, CEPEC n.v.; US n.v. (online image!)). Mun. Una: $6 \mathrm{~km}$ along the left side of the road to Vila Brasil, entrance of this road ca. $26 \mathrm{~km}$ from Una on the way to São José [da Vitória], spillage area for Reserva Biológica de Una, 1 May 2000 (fl), J.G. Jardim 3045 (CAS!, CEPEC n.v., NY n.v. (online image!)); road to Fazenda Aida Hartman, 30-50 m, 14 Oct 1983 (fr), G. Martinelli 9654 (CAS!, CEPEC n.v., RB n.v. (online image!), US n.v. (online image!)).

\section{ACKNOWLEDGMENTS}

The author thanks the curators of CAS, F, MICH, MO, NY, R, RB for loans of material on which this work was based, Manu Dal Forno for help with accessing specimen images and translating the abstract into Portuguese, Dr. Luís Carlos Bernacci for the image of the type specimen of Styrax kuhlmannii housed at IAC, two reviewers, i.e., Gerson Oliveira Romão and an anonymous reviewer, for helpful comments on the manuscript, and Samantha Peters for the illustration.

\section{REFERENCES}

Aranha, C. 1970. Nova espécie de Styracaceae para o Brasil. Atas Soc. de Biol. do Rio de Janeiro 13:79-81.

Asprino, R. \& A.M. Amorim. 2014. Flora da Bahia: Styracaceae. Sitientibus Sér. Ciênc. Biol. 13:10.13102/scb322. doi:10.13102/scb322

FloRA Do BRASIL 2020. 2020. Jardim Botânico do Rio de Janeiro. Available at http://floradobrasil.jbrj.gov.br/. Accessed July 2021.

FRITSCH, P.W. 1997. A revision of Styrax (Styracaceae) for western Texas, Mexico, and Mesoamerica. Ann. Missouri Bot. Gard. 84:705-761. 
FRITSCH, P.W. 1999. Phylogeny of Styrax based on morphological characters, with implications for biogeography and infrageneric classification. Syst. Bot. 24:355-378. doi:10.2307/2419695

FRITSCH, P.W. 2001. Phylogeny and biogeography of the flowering plant genus Styrax (Styracaceae) based on chloroplast DNA restriction sites and DNA sequences of the internal transcribed spacer region. Molec. Phylogen. Evol. 19:387-408. doi:10.1006/mpev.2001.0933

FRITSCH, P.W. 2004. New species and taxonomic changes in Styrax (Styracaceae) from South America. Novon 14:43-57. Stable URL: https://www.jstor.org/stable/3393437

FRITSCH, P.W. 2010. Styracaceae. In: R.C. Forzza et al., eds. Catálogo de plantas e fungos do Brasil. Jardim Botânico do Rio de Janeiro, Brazil 2:1649-1650.

FrITSCH, P.W. 2015. Two new species of Styrax (Styracaceae) from South America. Novon 24:9-13. Stable URL: https:// www.jstor.org/stable/44165000

FRITSCH, P.W. 2017. A new species of Styrax (Styracaceae) from Peru. Novon 25:282-285. doi:10.3417/D-16-00009

FritsCH, P.W. \& J.A. SteYermaRK. 2005. Styracaceae. In: P.E. Berry, K. Yatskievych, \& B.K. Holst, eds. Flora of the Venezuelan Guayana. Missouri Botanical Garden Press, St. Louis, U.S.A. 9:283-289.

FriTsCH, P.W., S.A. MoRI, \& J.L. Brown. 2002. Styracaceae. In: S.A. Mori, G. Cremers, C.A. Gracie, J.-J. de Granville, S.V. Heald, M. Hoff, \& J.D. Mitchell, eds. Guide to the vascular plants of central French Guiana, Part 2, dicotyledons. Mem. New York Bot. Gard. 76:706-708.

Fritsch, P.W., B.C. Cruz, W.B. Simison, A.J. Campbell, \& J.K. HarRis. 2015. Early phylogenetic divergence of gynodioecious species warrants the recognition of subseries in Styrax series Valvatae. Syst. Bot. 40:1081-1092. doi:10.1600/036364415X690120

HUANG, Y.-L., P.W. FriTsCH, \& S.-H. SHI. 2003. A revision of the imbricate group of Styrax series Cyrta (Styracaceae) in Asia. Ann. Missouri Bot. Gard. 90:491-553.

IUCN Standards and Petitions Subcommittee. 2019. Guidelines for using the IUCN Red List categories and criteria, ver. 14. Available at http://cmsdocs.s3.amazonaws.com/RedListGuidelines.pdf. Accessed April 2021.

LI, G. \& P.W. FRITSCH. 2018. A taxonomic revision of taxa in Styrax series Cyrta (Styracaceae) with valvate corollas. J. Bot. Res. Inst. Texas 12:579-641.

MoRI, S.A. \& L.A.M. SILVA. 1979. The herbarium of the "Centro de Pesquisas do Cacau" at Itabuna, Brazil. Brittonia 31:177-196.

Perkins, J. 1907. Styracaceae. In: A. Engler, ed. Das Pflanzenreich IV, 241 (Heft 30). Engelmann, Leipzig, Germany. Pp. $1-111$.

Thomas, W.W., A.M.V. Carvalho, A.M. Amorim, J.G. Hanks, \& T.S. Santos. 2008. Diversity of woody plants in the Atlantic coastal forest of southern Bahia, Brazil. In:W.W. Thomas, ed. The Atlantic coastal forests of northeastern Brazil. Mem. New York Bot. Gard. 100:21-66.

WALLnöFer, B. 1997. A revision of Styrax L. section Pamphilia (Mart. ex A.DC.) B. Walln. (Styracaceae). Ann. Naturhist. Mus. Wien, B, 99:681-720. Stable URL: http://www.jstor.org/stable/41767084 